\title{
Sexual dimorphism in the catfish Genidens genidens (Siluriformes: Ariidae) based on otolith morphometry and relative growth
}

\author{
Thaís Rodrigues Maciel ${ }^{1}$, André Martins Vaz-dos-Santos², \\ José Ricardo de Souza Barradas ${ }^{3}$ and Marcelo Vianna ${ }^{1}$
}

Genidens genidens is a species susceptible to population declines in view of their reproductive biology peculiarities. Morphometric differences between sexes are observed in the literature, and these differences should also be evident in otolith development. Growth patterns are one of the most important biological characteristics regarding population dynamics and management. In this context, the aim of the present study is to describe this species relative growth and identify differences between sex life cycles. Somatic growth-otolith growth relationships and somatic length-weight relationships were estimated based on two methodologies; the Huxley and the polyphasic allometric models. Both models demonstrated different growth patterns between sexes. The three axes of otolith growth were adequate descriptors of growth, and the results of the Huxley model demonstrated distinct growth patterns between sexes, with male otoliths larger in all three measured axes. In the polyphase model, male otoliths were thicker, while female otoliths were longer and higher. Both sexes presented similar length-weight relationships, which may indicate that oocyte production and parental care lead to similar costs for this species.

Keywords: Biphasic growth, Energy allocation, Growth models, lapillus otoliths, Morphometric relationships.

Genidens genidens é uma espécie suscetível a declínios populacionais, tendo em vista as peculiaridades de sua reprodução. Diferenças morfométricas entre os sexos são observadas na literatura, e essas diferenças também devem ser evidentes no desenvolvimento dos otólitos. O padrão de crescimento é uma das características biológicas mais importantes no que diz respeito à dinâmica populacional e manejo. Assim, nosso objetivo é descrever o crescimento relativo da espécie e identificar diferenças entre os ciclos de vida dos sexos. A relação crescimento somático-crescimento do otólito e a relação comprimentopeso somáticos foram estimados com base em duas metodologias, os modelos alométricos de Huxley e polifásico. Ambos os modelos demonstraram diferentes padrões de crescimento entre sexos. Os três eixos dos otólitos descreveram adequadamente o crescimento, e os resultados do modelo de Huxley demonstraram padrões de crescimento distintos entre os sexos, com os otólitos dos machos sendo maiores em todos os três eixos medidos. No modelo polifásico os otólitos dos machos foram maiores em espessura, enquanto os otólitos das fêmeas exibiram maior comprimento e altura. Ambos os sexos apresentaram relações de comprimento-peso semelhantes, o que pode indicar que a produção de ovócitos e o cuidado parental apresentam custos semelhantes para essa espécie.

Palavras-chave: Alocação de energia, Crescimento bifásico, Modelos de crescimento, Otólitos lapillus, Relações morfométricas.

\section{Introduction}

The catfish Genidens genidens (Cuvier, 1829) is distributed throughout the eastern coast of South America, from the Guianas to Rio de la Plata, in Argentina, and is one of the most common ariids on the Brazilian coast (Marceniuk, Menezes, 2007). This species is especially abundant in coastal lagoons and estuaries (Andrade-Tubino et al., 2008; Schmidt et al., 2008; Silva-Junior et al., 2013), including Guanabara Bay, one of the most degraded estuarine systems on the Brazilian coast (Meniconi et al., 2012). Despite this condition, Guanabara Bay supports the most productive estuarine fishery in the state of Rio de Janeiro (Prestrelo, Vianna, 2016). Silva-Junior et al. (2013) su-

\footnotetext{
${ }^{1}$ Instituto de Biologia, Universidade Federal do Rio de Janeiro, Av. Carlos Chagas Filho, 373, Ilha do Fundão, 21941-541 Rio de Janeiro, RJ, Brazil. (TRM) thaisrmaciel@gmail.com, ○https://orcid.org/0000-0002-5336-5607 (corresponding author), (MV) mvianna@biologia. ufrj.br, Ohttps://orcid.org/0000-0001-5871-8152

${ }^{2}$ Departamento de Biodiversidade, Universidade Federal do Paraná, Rua Pioneiro, 2153, Jardim de Dallas, 85950-000 Palotina, PR, Brazil. andrevaz@gmail.com, @ohttps://orcid.org/0000-0003-0620-9537

${ }^{3}$ Faculdade de Biociências, Pontifícia Universidade Católica do Rio Grande do Sul, Av. Ipiranga, 6681, Partenon, 90619-900 Porto Alegre, RS, Brazil.jrsbarradas@gmail.com, @ohttps://orcid.org/0000-0002-5517-7925
} 
ggest that $G$. genidens exhibits significant potential as a sentinel species for Guanabara Bay biomonitoring, since it completes its entire life cycle in this estuary, exhibits commercial importance, and demonstrates high tolerance to eutrophication and other anthropic impacts.

Growth is an important component of fish life history (Vaz-dos-Santos, 2015; Weatherley, 1966). The energy intake of an individual is directed to body mass development in the juvenile stage and both body mass and reproductive elements in adults (King, 1995). Consequently, different developmental patterns are observed throughout fish life cycles, detected through both length and weight growth rates and biometric ratios between different body parts (Bervian et al., 2006; Vaz-dos-Santos, 2015). Age variations in individual shape can be expressed through variations between the different somatic magnitudes of an organism, called relative growth (Bagenal, Tesch, 1978; Huxley, Teisser, 1936; Vaz-dos-Santos, 2015). Many fish species may exhibit differences between female and male growth rates (Martins, Haimovici, 2000; Newman et al., 2000; Yoneda et al., 2002; Vaz-dos-Santos, 2015). Paiva et al. (2015) demonstrated that, although G. genidens does not present evident sexual dimorphism body biometry, significant differences are observed, mainly in head and mouth measurements, related to the oropharyngeal incubation of offspring carried out by males. Additionally, Maciel et al. (2018b) found differences between growth parameters for males and females for this species. Thus, growth differences between males and females are also expected in other representative development elements, such as otoliths. Fish present three otolith pairs (Panfili et al., 2002) and, in Siluriformes, lapilli otoliths are larger than the other pairs, distinguishing these fish from other teleosts (Fuchs, Volpedo, 2009).

In particular, morphometry applications to otolith development provide a powerful and accurate tool by combining allometric model advantages and relative growth evaluations (Campana, 2001; Perin, Vaz-dos-Santos, 2014; Vaz-dos-Santos, 2015). The power function $\left(\mathrm{y}=a \mathrm{x}^{b}\right)$, originally applied by Huxley (1924) to describe allometric growth (shape variations related to size variations), has been conventionally applied to animal growth studies (Bervian et al., 2006), establishing a conceptual framework for the use of size relationships in morphometric studies (Perin, Vaz-dos-Santos, 2014). However, in spite of its frequent use, the Huxley model is limited in some cases regarding the adequate description of relative growth, since the $b$ coefficient can change during the organisms' life cycle (Bervian et al., 2006). These authors emphasize the importance of a residual analysis to verify the adequacy of the adjusted model and the constancy (or not) of the $b$ coefficient throughout development, proposing methodological alternatives to the model when growth is polyphasic. Given otolith usefulness as a record of individual (and hence population) growth, somatic growth-otolith growth relationship evaluations may indicate factors that affect this proportionality throughout fish life cycles (Hare, Cowen, 1995), such as differences between male and female development.

Considering that growth patterns are one of the most important biological population dynamic characteristics, also important in the management of exploited species (Alós et al., 2010a), and based on the premise of marked differences between male and female life cycles, the hypothesis presented herein is that these differences are reflected in sexual dimorphism concerning otolith morphometry and relative growth. Therefore, the aim of this study was to describe the relative growth of the catfish Genidens genidens based on lapilli otoliths, identifying possible differences between development of males and females.

\section{Material and Methods}

Genidens genidens individuals were obtained every 15 days from artisanal fishing landings at five points distributed throughout the Guanabara Bay estuary, RJ $\left(22^{\circ} 50^{\prime} \mathrm{S}\right.$ and $\left.43^{\circ} 10^{\prime} \mathrm{W}\right)$, between January 2014 and January 2015 (Fig. 1). Specimens were deposited at the $\mathrm{Na}$ tional Museum of Rio de Janeiro collection (voucher specimens: MNRJ 42040). Individual biometry was carried out, determining total length (Lt, $0.1 \mathrm{~cm}$ precision) and total weight (Wt, $0.001 \mathrm{~g}$ precision). An abdominal incision was performed for macroscopic sex identification. In immature individuals, sex identification was confirmed by histological analyses according to Brown-Peterson et al. (2011).

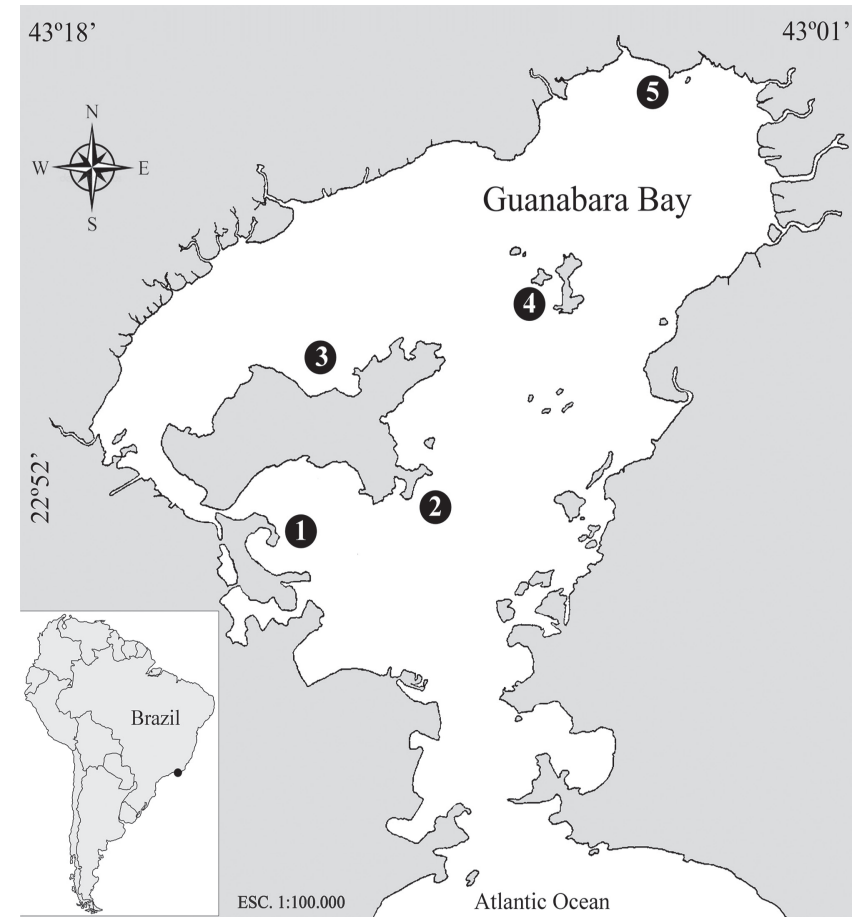

Fig. 1. Guanabara Bay, Rio de Janeiro, Southeastern Brazil, indicating the sampling sites: 1- Bancários, 2 - Magé, 3 Paquetá Island, 4 - Ilha do Fundão, 5 - central channel. 
For otolith pair removal, cranial cavity sectioning was performed and maximum length (Lo), height (Ho) and thickness (To) were obtained for each left lapillus otolith (Fig. 2), using a digital caliper ( $0.01 \mathrm{~mm}$ accuracy), while weight (Wo) was determined using an electronic balance (0.0001 $\mathrm{g}$ accuracy).

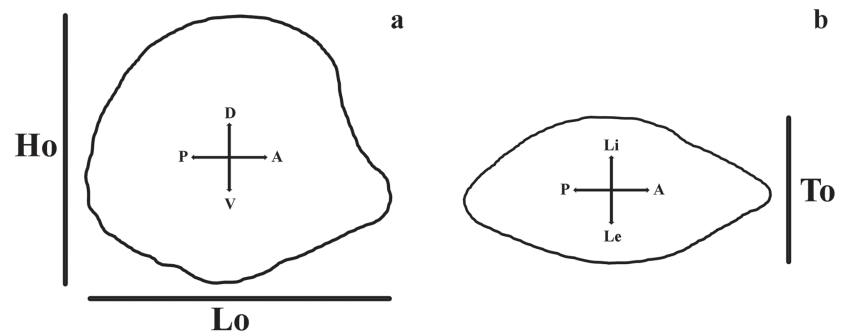

Fig. 2. Schematic representation of Genidens genidens otolith measurements: maximum length (Lo), maximum height (Ho) and maximum thickness (To). a. Lateral view; b. lateroventral view. Structures: dorsal (D), ventral (V), posterior $(\mathrm{P})$, anterior $(\mathrm{A})$, internal lateral face $(\mathrm{Li})$ and external lateral face (Le) position relative to the fish.

To support interpretations regarding changes in morphometric otolith patterns, the otoliths were photographed, and an illustrative schematic of male and female lapilli otoliths during different development stages was elaborated. The relationships between somatic and otolith growth for G. genidens males and females were estimated based on two methodologies, by adjusting the traditional power model (Huxley, 1924) and the polyphasic model (Bervian et al., 2006, modified by Barradas et al., 2016). The latter approach considers a growth pattern comprising two distinct phases, separated by a stanza changing point (SCP), which indicates the Lt at the time individual growth pattern changed.

The Huxley allometric model $\left(\mathrm{y}=a \mathrm{x}^{b}\right)$ was adjusted using $\mathrm{Lt}$ as the independent variable and Lo, Ho, To, Wo as dependent variables. The nonlinear least squares method was applied to the proportional residuals to y through the Levenberg-Marquardt algorithm using the nlsLM function present in the minpack.lm (Elzhov et al., 2016) package of the statistical platform R (R Core Team, 2017). Due to the naturally occurring heteroscedasticity of this data set, homocedastic residues were used for model fit, instead of gross residues (Barradas et al., 2016).

For the polyphasic model analysis, the moving average of the residuals was used to verify the somatic length range in which changes in male and female growth patterns occur, by observing the trends for each point. Each growth phase was described by a power equation. Both growth phases were described by:

$$
W=\left[\left(a_{1} L^{b_{1}}\right) \cdot F_{w}\right]+\left[\left(a_{2} L^{b_{2}}\right) \cdot\left(1-F_{w}\right)\right]
$$

where $\mathrm{W}$ is the weight, $a_{1}$ and $a_{2}$ are the proportionality coefficients relative to each growth stage, $L$ is the length, $b_{1}$ and $b_{2}$ are the allometry coefficients relative to each growth stage and $F w$ is the switch function.
The switch function is a logistic function that varies between 0 and 1 and that acts by "turning on" and "turning off" equations referring to growth. It is a phase multiplier, described by:

$$
F_{w}=\frac{1}{1+e^{R_{S c}} \cdot(L-S C P)}
$$

where $F w$ is the switch function, $R_{S C}$ is the stage change rate - which indicates the transition speed between phase 1 and phase 2, $L$ is the length and $S C P$ is the length corresponding to the stanza changing point.

Model evaluation was based on residual significance, tested by a linear regression between the homocedastic residual and length, which are expected to be randomly distributed, and by the Akaike Information Criterion (AIC), which varies according to the sum of the least squares of the residual and the number of parameters in each tested model. The Huxley and polyphasic models were also applied as described above to compare the somatic length-weight relationship (LWR) between males and females.

\section{Results}

Biometric data was obtained for the left lapillus otolith of $730 \mathrm{G}$. genidens females, with Lt ranging from 6.0 to $37.0 \mathrm{~cm}$, and 377 males, with Lt between 5.0 and $36.0 \mathrm{~cm}$. The general lapilli shape variation pattern throughout male and female development was similar for different sizes (Fig. 3 ), where lapilli in individuals up to $28.0 \mathrm{~cm}$ in total length acquire their "adult" form and when fish grow to greater lengths, and a higher increase occurs in a three-dimensional perspective, visually revealed by thickness increases.

Tables 1-2 exhibit the results of the relative growth analyses by the Huxley and the polyphasic allometric models. Graphic representations can be consulted in supplementary material (S1 - S10 - Available only as online supplementary file accessed with the online version of the article at http://www. scielo.br/ni). The residal analysis for the polyphasic model ensured the adequacy of the adjusted model and the identification of fish life stages, except for the Lt-Wo ratio in females, as residual exhibited a trend $(p<0.05)$. The model presenting the lower AIC, and, consequently, representing the best otolith growth, was the Lt-Lo ratio for both sexes in both the Huxley and polyphasic models. AIC values were high for both male and female Lt-Wo ratios, indicating that this relationship is not the most adequate to describe $G$. genidens growth.

The stanza changing rate $\left(R_{S C}\right)$, which controls the rate at which the change in growth patterns occurs, was higher in males ( 7.2 to 12.0) compared to females (between 1.2 to 9.6), indicating that this change may be more pronounced in males. Female $S C P$ was calculated between 26.8 and $31 \mathrm{~cm}$, while male $S C P$ ranged between 26 and $29.2 \mathrm{~cm}$. This indicates that males alter their growth pattern to a smaller body size compared to females. Regarding G. genidens ontogenetic development, otolith growth was more pronounced in smaller individuals for all somatic growth-otolith growth relationships, and was decreased in larger fish $\left(b_{1}>b_{2}\right)$. 


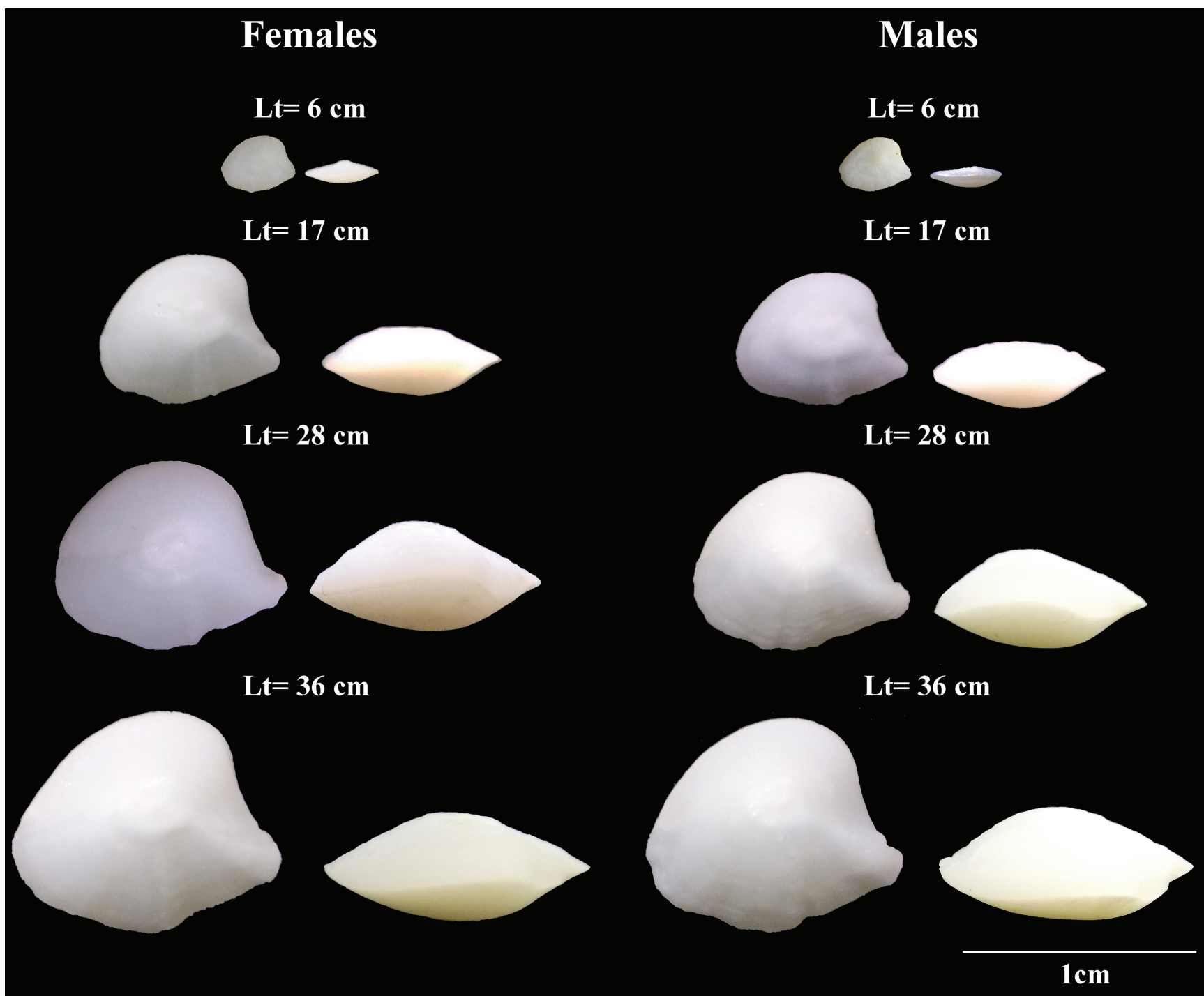

Fig. 3. Lapilli otoliths from Genidens genidens females and males from Guanabara Bay, Rio de Janeiro, southeastern Brazil.

Tab. 1. Relative Genidens genidens females growth ratios, calculated by the Huxley (1924) and the polyphasic allometric models ( $\mathrm{SE}=$ standard error), in specimens obtained from Guanabara Bay, Rio de Janeiro, southeastern Brazil.

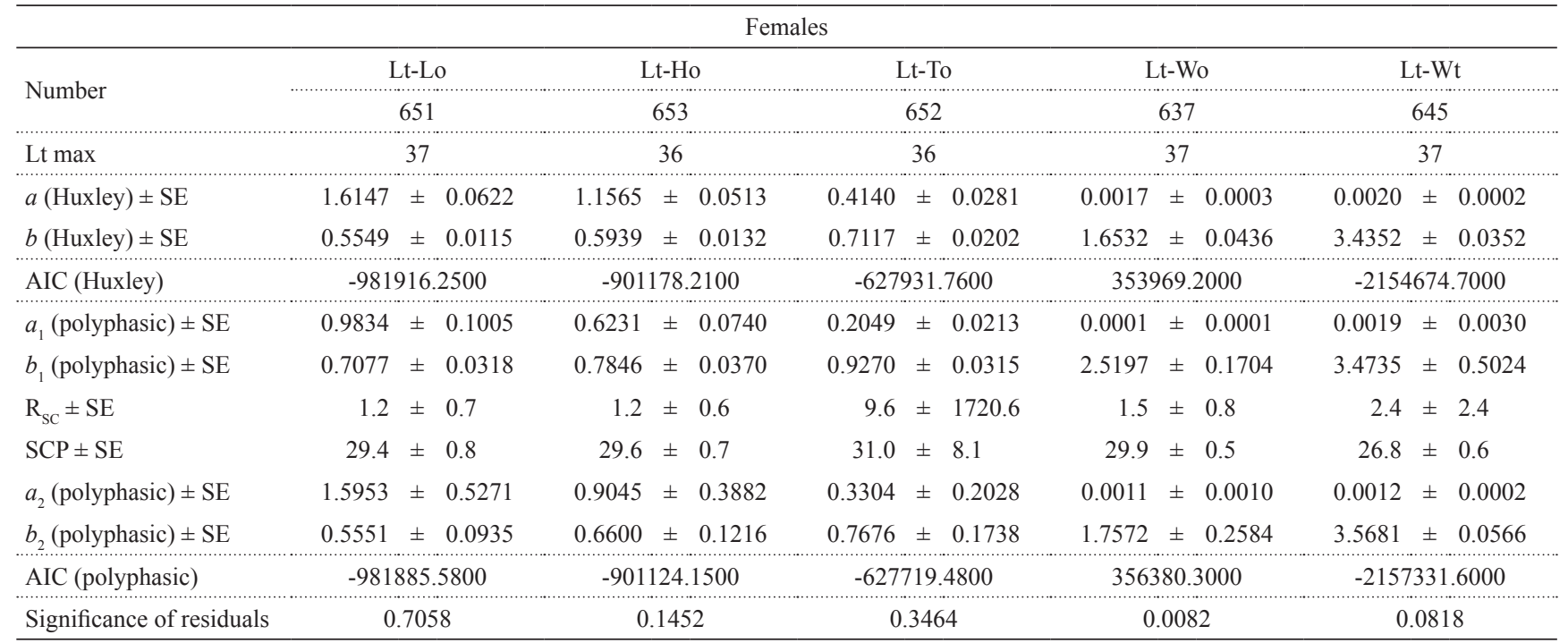


Tab. 2. Relative Genidens genidens males growth ratios, calculated by the Huxley (1924) and the polyphasic allometric models $(\mathrm{SE}=$ standard error), in specimens obtained from Guanabara Bay, Rio de Janeiro, southeastern Brazil.

\begin{tabular}{|c|c|c|c|c|c|}
\hline \multicolumn{6}{|c|}{ Males } \\
\hline \multirow{2}{*}{ Number } & Lt-Lo & Lt-Ho & Lt-To & Lt-Wo & Lt-Wt \\
\hline & 334 & 340 & 334 & 330 & 334 \\
\hline Lt max & 36 & 36 & 36 & 36 & 36 \\
\hline$a$ (Huxley) $\pm \mathrm{SE}$ & $1.3570 \pm 0.0546$ & $0.9954 \pm 0.0455$ & $0.3114 \pm 0.0216$ & $0.0009 \pm 0.0002$ & $0.0012 \pm 0.0002$ \\
\hline$b$ (Huxley) $\pm \mathrm{SE}$ & $0.6065 \pm 0.0121$ & $0.6379 \pm 0.0137$ & $0.7946 \pm 0.0207$ & $1.8231 \pm 0.0496$ & $3.5836 \pm 0.0468$ \\
\hline AIC (Huxley) & -254309.7700 & -239601.8600 & -159013.3200 & 105201.5700 & -558365.4700 \\
\hline$a_{1}($ polyphasic $) \pm \mathrm{SE}$ & $0.9940 \pm 0.0957$ & $0.6696 \pm 0.0719$ & $0.1954 \pm 0.0225$ & $0.0002 \pm 0.0002$ & $0.0050 \pm 0.0052$ \\
\hline$b_{1}($ polyphasic $) \pm \mathrm{SE}$ & $0.7041 \pm 0.0310$ & $0.7621 \pm 0.0345$ & $0.9415 \pm 0.0356$ & $2.2441 \pm 0.2901$ & $3.1529 \pm 0.3216$ \\
\hline $\mathrm{R}_{\mathrm{SC}} \pm \mathrm{SE}$ & $12.0 \pm 769.8$ & $12.0 \pm 39305.1$ & $12.0 \pm 3148.7$ & $7.2 \pm 333.9$ & $12.0 \pm 14631.0$ \\
\hline $\mathrm{SCP} \pm \mathrm{SE}$ & $26.4 \pm 27.4$ & $27.0 \pm 120.3$ & $29.2 \pm 61.4$ & $26.0 \pm 1.1$ & $27.2 \pm 184.2$ \\
\hline$a_{2}($ polyphasic $) \pm \mathrm{SE}$ & $2.2639 \pm 0.2263$ & $1.9475 \pm 0.2158$ & $0.2615 \pm 0.1023$ & $0.0028 \pm 0.0008$ & $0.0006 \pm 0.0002$ \\
\hline$b_{2}($ polyphasic $) \pm \mathrm{SE}$ & $0.4571 \pm 0.0291$ & $0.4421 \pm 0.0323$ & $0.8412 \pm 0.1119$ & $1.5093 \pm 0.0807$ & $3.7591 \pm 0.0802$ \\
\hline AIC (polyphasic) & -254293.4000 & -239565.2400 & -158904.1600 & 106643.5200 & -560660.6000 \\
\hline Significance of residuals & 0.9205 & 0.0586 & 0.1215 & 0.6854 & 0.3223 \\
\hline
\end{tabular}

The $b$ coefficient values in both allometric model equations show that the Lt-Lo, Lt-Ho and Lt-To relationships present negative allometry $(b<1)$. This indicates that increases in somatic length were proportionally greater than otolith growth in the three measured axes (Lo, Ho and To). Based on the Huxley model results, males exhibit larger otoliths concerning length, height and thickness compared to females ( $b$ males $>b$ female). The polyphasic model, however, indicates that female otoliths are larger than male otoliths regarding length and height $\left(b_{1}\right.$ females $>b_{1}$ males; $b_{2}$ females $>b_{2}$ males), but thinner ( $b_{1}$ females $<b_{1}$ males; $b_{2}$ females $<b_{2}$ males) during both, the first and second growth stages.

Concerning the somatic length-weight relationship, growth presented a positive allometry $(b>3)$, indicating that weight increases are proportionally greater than length increases. Throughout ontogenetic development, weight gain is proportionally lower in small individuals, increasing with individual growth $\left(b_{1}<b_{2}\right)$, for both sexes. Both models indicate that males exhibit greater somatic weight $(\mathrm{Wt})$ at the same length as females ( $b$ females $<b$ males; $b_{2}$ females $<b_{2}$ males).

\section{Discussion}

Genidens genidens lapilli otoliths reflect polyphasic growth in relation to body growth, and a differentiated growth pattern between males and females was identified. Traditionally, growth pattern studies between body and otoliths consider these relationships to be constant throughout fish development, limiting interpretations regarding life cycle events that affect otolith development (Bervian et al., 2006). Ontogenic growth pattern changes are well documented, emphasizing the importance of considering this variable in growth studies. For example, Hare, Cowen
(1995) detected changes in the relationship between otolith size and body size throughout different Pomatomus saltatrix (Linnaeus, 1766) (Pomatomidae) ontogenetic stages, while Alós et al. (2010a) and Alós et al. (2010b) identified ontogenetic changes in Diplodus annularis (Linnaeus, 1758) (Sparidae) and in Serranus scriba (Linnaeus, 1758) (Serranidae) growth rates, respectively, inferring that this change is related to different energy allocations between reproductive and somatic activities at different ages. Alós et al. (2010a) emphasize that neglecting ontogenetic changes in individual life history parameters can lead to serious issues, especially in growth studies, suggesting the inclusion of an initial and final growth rate in the von Bertalanffy model, representing different growth energy allocations before and after sexual maturity, while Bervian et al. (2006), identifying the same problem, suggest the application of a polyphasic model to describe growth.

Relative $G$. genidens body and otolith growth presented negative allometry $(b<1)$, similar to that described for other teleost species (e.g. Labropoulou, Papaconstantinou, 2000; Perin, Vaz-dos-Santos, 2014), indicating that somatic length growth is proportionally greater than otolith growth.

Maciel et al. (2018b) observed differences between male and female $G$. genidens concerning growth parameters and age, estimated from otoliths, while Paiva et al. (2015) observed intersex differences for morphometric body measurements. The results reported herein indicate that these intersex morphometric differences also apply to otoliths, since the Huxley model demonstrated that male otoliths are proportionally larger in all three measured axes, while the polyphasic model indicates that female otoliths are larger in length and height, and that male otoliths are thicker in both developmental stages. Since otolith shape may reflect body shape (Perin, Vaz-dos-Santos, 2014), thicker otoliths in males may reflect higher body growth rates in this dimension, 
while females may exhibit greater body growth in length and height. Sexual dimorphism in otolith growth patterns has also been described for other teleosts, such as species belonging to the Ophidiidae family (Schwarzhans, 1994), Prionotus nudigula Ginsburg, 1950 (Triglidae) (Volpedo, Thompson, 1998), Coryphaena hippurus Linnaeus, 1758 (Coryphaenidae) (Morales-Nin et al., 1999) and Porichthys notatus Girard, 1854 (Batrachoididae) (Bose et al., 2016).

Ontogenetic changes in intersex growth parameters were also detected. The polyphasic allometric model data indicated that G. genidens undergoes two growth stages, in both sexes, between 26.0 and $29.2 \mathrm{~cm}$ for males and between 26.8 and $31.0 \mathrm{~cm}$ for females. Several factors can affect fish growth patterns, such as migration, sexual maturity and food availability, among others (Weatherley, Gill, 1987; Wootton, 1998; Busacker et al., 1990; Saborido- Rey, Kjesbu, 2005; Vaz-dos-Santos, 2015). Particularly, reproductive efforts negatively affect growth, as more energy is directed to somatic growth during the juvenile phase, leading to rapid length growth, which decreases when fish become adults, since energy is divided between two processes (reproduction and growth) (Haimovici, Reis, 1984; Vazzoler, 1996; Pandian, 2010). For G. genidens, who presents a very complex reproductive cycle, with females producing among the largest oocytes in all teleosts (Wallace, Selman, 1981) and males performing oral offspring incubation, when they maintain a fasting state (Chaves, 1994; Garcia et al., 2006), reproductive activity seems to be the determining factor for the growth pattern changes observed herein.

Considering that the $\mathrm{L}_{100}$ value for $G$. genidens males was calculated at $28.2 \mathrm{~cm}$ (Maciel et al., 2018a), the SCP seems to be related to the size in which all males in a given population become mature. For females, although Maciel et al. (2018a) calculated that all females of a given population were already adults at $19.3 \mathrm{~cm}\left(\mathrm{~L}_{100}\right)$, the same study shows they skip spawning and only begin to spawn at $20 \mathrm{~cm}$, and from $28 \mathrm{~cm}$ a considerable increase in fecundity is detected, suggesting that these females reabsorb produced oocytes and skip the reproductive period in order to invest energy in growth, beginning actual reproductive activities when they reach larger body sizes and are more fecund. Folkvord et al. (2014) demonstrated that immature fish or those who skipped the spawning season exhibited more pronounced growth rates than individuals carrying out reproduction activities. Thus, SCP size in females seems to be related to a reproductive strategy aiming at increased fertility, rather than sexual maturation. Since fecundity is related to size increases in this species (Maciel et al., 2018a), the changes in growth pattern occur when individuals are at the peak of their reproductive activity.

The somatic length-weight relationship in $G$. genidens exhibited positive allometry $(b>3)$, demonstrating that weight increases are greater than somatic growth, as described by Oliveira, Novelli (2005) for the same species at Lagoa do Açú (RJ). Weight gain was proportionally higher during the second growth stage for both sexes, when individuals invest less in length growth, probably due to reproductive activity costs (Perin, Vaz-dos-Santos, 2014). The data reported herein also suggest that females presented lower weights at the same length as males, in contrast to what was reported by Araújo et al. (1998). However, the $b$ values generated by both models for each sex are close, suggesting that weight gains for both males and females are similar. Since the somatic length-weight relationship reflects individual living conditions related to feeding, migration and reproduction (King, 1995), this may indicate that the parental care process performed by males, which can last from two to three months (Barbieri et al., 1992), is almost as energetically costly as the production of large oocytes by females, since males remain in fasting conditions throughout this period, as their oropharyngeal cavity remains blocked by offspring (Araújo, 1988; Chaves, 1994; Garcia et al., 2006).

This study demonstrates the importance of otolith morphometry in determining the occurrence of sexual dimorphism in G. genidens, related to the reproductive biology of the species. The Huxley and polyphasic allometric models were adequate in revealing differential growth patterns between males and females, with the latter doing so in more details. These results are relevant to a better understanding of the ontogenetic development of the species, also serving as subsidy for age estimation studies.

\section{Acknowledgments}

The authors are grateful to the UFRJ Laboratório de Biologia e Tecnologia Pesqueira and UFPR Laboratório de Esclerocronologia team for their assistance in material processing and for their helpful comments in the discussion, especially Sérgio Santos and Luana Prestrelo. The authors are also grateful to the artisanal fishermen for their help in obtaining the biological material. The authors also acknowledge Conselho Nacional de Desenvolvimento Científico e Tecnológico (MV, AMVS and TRM), the Programa de Pesquisas Ecológicas de Longa Duração-Baía de Guanabara (CNPq PELD 403809/2012-6) and Fundação de Amparo à Pesquisa do Estado do Rio de Janeiro (MV) (FAPERJ E26/112.636/2012, E26/110.114/2013 and E26/201.334/2014) for the awarded grants. All the biological material was obtained according to Brazilian environmental legislation and with scientific fishing license. We also thank Rachel Ann Hauser-Davis for editing English syntax and grammar.

\section{References}

Alós J, Palmer M, Alonso-Fernández A, Morales-Nin B. Individual variability and sex-related differences in the growth of Diplodus annularis (Linnaeus, 1758). Fish Res. 2010a; 101(1-2):60-69. Available from: https://doi.org/10.1016/j.fishres.2009.09.007

Alós J, Palmer M, Balle S, Grau AM, Morales-Nin B. Individual growth pattern and variability in Serranus scriba: a Bayesian analysis. ICES J Mar Sci. 2010b; 67:502-12. Available from: https://doi.org/10.1093/icesjms/fsp265 
Andrade-Tubino MF, Ribeiro ALR, Vianna M. Organização espaçotemporal das ictiocenoses demersais nos ecossistemas estuarinos brasileiros: uma síntese. Oecologia Bras. 2008; 12:640-61. Available from: https://doi.org/10.4257/oeco.2008.1204.05

Araújo FG, Gomes ID, Azevedo MCC, Pessanha ALM. Maturação e desova do bagre marinho Genidens genidens Valenciennes, 1833 (Siluriformes, Ariidae), na Baía de Sepetiba, RJ. Acta Biol Leopoldensia. 1998; 20(1):109-22.

Araújo FG. Distribuição, abundância relativa e movimentos sazonais de bagres marinhos (Siluriformes, Ariidae) no estuário da Lagoa dos Patos (RS), Brasil. Rev Bras Zool. 1988; 5(4):509-43. Available from: https://doi.org/10.1590/S010181751988000400002

Bagenal TB, Tesch FW. Age and growth. In: Bagenal TB, editor. Methods for assessment of fish production in fresh waters. 3rd Ed. Oxford: Blackwell Scientific Publications; 1978. p.101-36.

Barbieri LR, Santos RP, Andreata JV. Reproductive biology of the marine catfish, Genidens genidens (Siluriformes, Ariidae), in the Jacarepaguá Lagoon system, Rio de Janeiro, Brazil. Environ Biol Fishes. 1992; 35(1):23-35. Available from: https://doi.org/10.1007/BF00001154

Barradas JRS, Lermen IS, Larré GG, Martins TP, Fontoura NF. Polyphasic growth in fish: a case study with Corydoras paleatus (Siluriformes, Callichthyidae). Iheringia Série Zool. 2016; 106: e2016017. Available from: https://doi.org/10.1590/16784766e2016017

Bervian G, Fontoura NF, Haimovici M. Statistical model of variable allometric growth: otolith growth in Micropogonias furnieri (Actinopterygii, Sciaenidae). J Fish Biol. 2006; 68(1):196-208. Available from: https://doi.org/10.1111/j.00221112.2006.00890.x

Bose APH, Adragna JB, Balshine S. Otolith morphology varies between populations, sexes and male alternative reproductive tactics in a vocal toadfish Porichthys notatus. J Fish Biol. 2017; 90(1):311-25. Available from: https://doi.org/10.1111/jfb.13187

Brown-Peterson NJ, Wyanski DM, Saborido-Rey F, Macewicz BJ, Lowerre-Barbieri SK. A standardized terminology for describing reproductive development in fishes. Mar Coast Fish. 2011; 3(1):52-70. Available from: https://doi.org/10.1080/1942 5120.2011 .555724

Busacker GP, Adelman IR, Goolish EM. Growth. In: Schreck CB, Moyle PB, editors. Methods for fish biology. Bethesda: American Fisheries Society; 1990. p.363-387.

Campana SE. Accuracy, precision and quality control in age determination, including a review of the use and abuse of age validation methods. J Fish Biol. 2001; 59(2):197-242. Available from: https://doi.org/10.1006/jfbi.2001.1668

Chaves PTC. A incubação de ovos e larvas em Genidens genidens (Valenciennes) (Siluriformes, Ariidae) da Baía de Guaratuba, Paraná, Brasil. Rev Bras Zool. 1994; 11(4):641-48. Available from: https://doi.org/10.1590/S0101-81751994000400008

Elzhov ATV, Mullen KM, Spiess A-N, Bolker B, Mullen MKM. minpack.lm: R Interface to the Levenberg-Marquardt Nonlinear Least-Squares Algorithm Found in MINPACK, Plus Support for Bounds. 2016; 1-14. Available from: https://cran.r-project. org/web/packages/minpack.lm/minpack.lm.pdf
Folkvord A, Jørgensen C, Korsbrekke K, Nash RDM, Nilsen T, Skjaeraasen JE. Trade-offs between growth and reproduction in wild Atlantic cod. Can J Fish Aquat Sci. 2014; 71:1106-12. Available from: https://doi.org/10.1139/cjfas-2013-0600

Fuchs DV, Volpedo AV. Morfología de lapillus de Siluriformes Parano-Platenses. Biol Acuática. 2009; 26:97-108.

Garcia AM, Vieira JP, Burns MDM. Genidens genidens (Cuvier) (Pisces, Ariidae), oral incubation of eggs. Panam J Aquat Sci. 2006; 1(2):I. Available from: https://panamjas.org/pdf_ conteudos/PANAMJAS_1(2)_I.pdf

Haimovici M, Reis EG. Determinação de idade e crescimento da castanha Umbrina Canosai (Pisces, Sciaeinidae) do Sul do Brasil. Atlântica. 1984; 7:25-46.

Hare JA, Cowen RK. Effect of age, growth rate, and ontogeny on the otolith size - fish size relationship in bluefish, Pomatomus saltatrix, and the implications for back-calculation of size in fish early life history stages. Can J Fish Aquat Sci. 1995; 52(9):1909-22. Available from: https://doi.org/10.1139/f95-783

Huxley JS, Teissier G. Terminology of Relative Growth. Nature. 1936; 137:780-81. Available from: https://doi. org/10.1038/137780b0

Huxley JS. Constant differential growth-ratios and their significance. Nature. 1924; 114:895-96. Available from: https:// doi.org/10.1038/114895a0

King M. Fisheries biology, assessment and management. Oxford: Blackwell Science Ltd.; 1995.

Labropoulou M, Papaconstantinou C. Comparison of otolith growth and somatic growth in two macrourid fishes. Fish Res. 2000; 46(1-3):177-88. Available from: https://doi.org/10.1016/ S0165-7836(00)00144-2

Maciel TR, Vaz-dos-Santos AM, Caramaschi EP, Vianna M. Management proposal based on the timing of oral incubation of eggs and juveniles in the sentinel species Genidens genidens (Siluriformes: Ariidae) in a tropical estuary. Neotrop Ichthyol. 2018a; 16(4):e170119. Available from: https://doi. org/10.1590/1982-0224-20170119

Maciel TR, Vaz-dos-Santos AM, Vianna, M. Can otoliths of Genidens genidens (Cuvier 1829) (Siluriformes: Ariidae) reveal differences in life strategies of males and females? Environ Biol Fish. 2018b; 101(11):1589-98. Available from: https://doi.org/10.1007/s10641-018-0804-5

Marceniuk AP, Menezes NA. Systematics of the family Ariidae (Ostariophysi, Siluriformes), with a redefinition of the genera. Zootaxa. 2007; 1416:1-126.

Martins RS, Haimovici M. Determinação da idade, crescimento e longevidade da abrótea de profundidade, Urophycis cirrata Goode and Bean, 1896 (Teleostei: Phycidae) no extremo Sul do Brasil. Atlântica. 2000; 22:57-70.

Meniconi MFG, Silva TA, Fonseca ML, Lima SOF, Lima EFA, Lavrado HP, Figueiredo-Jr. AG. Baía de Guanabara: Síntese do conhecimento ambiental - v. 2. Biodiversidade. Rio de Janeiro: Petrobrás; 2012.

Morales-Nin B, Stefano M, Potoschi A, Massutí E, Rizzo P, Gancitano $\mathrm{S}$. Differences between the sagitta, lapillus and vertebra in estimating age and growth in juvenile Mediterranean dolphinfish (Coryphaena hippurus). Sci Mar. 1999; 63(3-4):327-36. 
Newman SJ, Cappo M, Williams DM. Age, growth and mortality of the stripey, Lutjanus carponotatus (Richardson) and the brown-stripe snapper, L. vitta (Quoy and Gaimard) from the central Great Barrier Reef, Australia. Fish Res. 2000; 48(3):263-75. Available from: https://doi.org/10.1016/S01657836(00)00184-3

Oliveira MR, Novelli R. Idade e crescimento do bagre Genidens genidens na barra da Lagoa do Açú, norte do estado do Rio de Janeiro. Trop Oceanogr. 2005; 33:57-66.

Paiva LG, Prestrelo L, Sant'Anna KM, Vianna M. Biometric sexual and ontogenetic dimorphism on the marine catfish Genidens genidens (Siluriformes, Ariidae) in a tropical estuary. Lat Am J Aquat Res. 2015; 43(5):895-903. Available from: https://doi. org/10.3856/vol43-issue5-fulltext-9

Pandian TJ. Sexuality in fishes. Enfield: Science Publishers; 2010.

Panfili J, Pontual H, Troadec H, Wright P. Manual of fish sclerochronology. Brest: Ifremet-IRD; 2002.

Perin S, Vaz-dos-Santos AM. Morphometry and relative growth of the Brazilian sardine, Sardinella brasiliensis (Steindachner, 1879) in the southeastern Brazilian bight. Arq Zool. 2014; 45:63-72. Available from: https://doi.org/10.11606/issn.21767793.v45iespp63-72

Prestrelo L, Vianna M. Identifying multiple-use conflicts prior to marine spatial planning: A case study of a multi-legislative estuary in Brazil. Mar Policy. 2016; 67:83-93. Available from: https://doi.org/10.1016/j.marpol.2016.02.001

R Development Core Team. R: a language and environment for statistical computing [Computer software manual - Internet]. Vienna: R Foundation for Statistical Computing; 2014. Available from: https://www.rproject.org/

Saborido-Rey F, Kjesbu OS. Growth and maturation dynamics. 2005. Availablefrom:http://digital.csic.es/bitstream/10261/47150/3/ Growth\%20and\%20maturation\%20dynamics\%20\%281\%29. pdfSchmidt TC dos S, Martins IA, Reigada ALD, Dias JF. Taxocenose de bagres marinhos (Siluriformes, Ariidae) da região estuarina de São Vicente, SP, Brasil. Biota Neotrop. 2008; 8(4):73-81. Available from: https://doi.org/10.1590/ S1676-06032008000400006
Schwarzhans W. Sexual and ontogenetic dimorphism in otoliths of the family Ophidiidae. Cybium. 1994; 18(1):71-98.

Silva-Junior DR, Carvalho DMT, Vianna M. The catfish Genidens genidens (Cuvier, 1829) as a potential sentinel species in Brazilian estuarine waters. J Appl Ichthyol. 2013; 29(6):1297-303. Available from: https://doi.org/10.1111/ jai. 12280

Vaz-dos-Santos AM. Otolitos en estudios de edad y crecimiento en peces. In: Volpedo AV, Vaz-dos-Santos AM, editors. Métodos de estudios con otolitos: principios y aplicaciones. Buenos Aires; 2015. p.93-122.

Vazzoler AEAM. Biologia da reprodução de peixes teleósteos: teoria e prática. São Paulo: EDUEM; 1996.

Volpedo AV, Thompson GA. Diferencias en el crecimiento de las sagittae de Prionotus nudigula Ginsburg, 1950 (Pistes: Triglidae) en relación al sexo. Bol Inst Esp Oceanogr. 1996; 12(1):3-16.

Wallace RA, Selman K. Cellular and dynamic aspects of oocyte growth in teleosts. Am Zool. 1981; 21(2):325-43. Available from: https://doi.org/10.1093/icb/21.2.325

Weatherley AH, Gill HS. The biology of fish growth. London: Academic Press; 1987.

Weatherley AH. Ecology of fish growth. Nature. 1966; 212:132124. Available from: https://doi.org/ 10.1038/2121321a0

Wootton RJ. Ecology of teleost fishes. 2nd ed. London: Kluwer Academic Publishers; 1998.

Yoneda M, Sakai T, Tokimura M, Horikawa H, Matsuyama M. Age and growth of the lizardfish Saurida sp. in the East China Sea using otolith ring marks. Fish Res. 2002; 55(13):231-38. Available from: https://doi.org/10.1016/S01657836(01)00285-5 